\title{
The community-level response to sewage impact in intertidal mytilid beds of the Southwestern Atlantic, and the use of the Shannon index to assess pollution
}

\author{
La respuesta al impacto cloacal a nivel comunitario en los bancos intermareales de \\ mitílidos del Atlántico sudoccidental, y el uso del índice de Shannon para \\ la determinación de contaminación
}

\section{Eduardo Alberto Vallarino, $\mathbf{M}^{\mathrm{a} \cdot}$ Silvia Rivero, $\mathbf{M}^{\mathrm{a} \cdot}$ Carola Gravina and Rodolfo Elías}

\author{
Universidad Nacional de Mar del Plata, Departamento de Ciencias Marinas, \\ Deán Funes 3350 (B 7602 AYL) Mar del Plata, Argentina. Fax 005402234753150 \\ evallari@mdp.edu.ar
}

\begin{abstract}
A study of an intertidal mytilid community in the Southwestern Atlantic shore was carried out in order to characterize the mytilid bed's response to an intertidal sewage discharge. Four Stations were sampled around the outfall, with a Control site. Total Weight and Organic Carbon content of sediments among mussels, as well as water quality variables were measured. All macrofauna were counted, and species number, Shannon's diversity index and evenness were calculated. The mytilid Brachidontes rodriguezi increases it density inversely to distance to the effluent. The polychaetes Capitella capitata and Boccardia polybranchia characterized the most impacted Stations, while crustaceans (Corophium insidiosum, Jassa falcata and Caprella sp.) were dominant at medial distances. Both environmental and biological data show significative differences between Stations. The most impacted Station has the lowest species number, but the highest values of both diversity and evenness; while control Station has the lowest values of diversity and evenness. The study reject the use of univariate indices to assess organic pollution in this community, being the presence of indicator species with mytilid proportion the best tool for sewage impact assessment.

Keywords: mytilid beds, community structure, univariate index, intertidal sewage, Southwestern Atlantic.
\end{abstract}

Resumen. - Se realizó un estudio de la comunidad intermareal de mitílidos del Atlántico sudoccidental con el objetivo de caracterizar su respuesta a la descarga de un efluente cloacal intermareal. Cuatro estaciones fueron muestreadas en el área impactada, más un sitio Control. Peso total y contenido orgánico fueron medidos del sedimento retenido entre los bivalvos, al igual que variables de calidad del agua. Toda la macrofauna fue contada, y el número de especies, diversidad y equitatividad fueron calculadas. El mitílido Brachidontes rodriguezi incrementa su densidad en forma inversa a la distancia al efluente. Los poliquetos Capitella capitata y Boccardia polybranchia caracterizan las estaciones más impactadas, mientras que los crustáceos (Corophium insidiosum, Jassa falcata y Caprella sp.) fueron dominantes a distancias intermedias. Tanto los datos ambientales como los biológicos muestran diferencias significativas entre estaciones. La estación más impactada tiene el más bajo número de especies, aunque los más altos valores de diversidad y equitatividad, mientras que el sitio Control tiene los más bajos. En este estudio se rechaza el uso de índices univariantes para la determinación de contaminación orgánica por efluentes cloacales en esta comunidad. La mejor herramienta de análisis resultó ser la presencia de especies indicadoras y la proporción de mitílidos. Palabras clave: bancos de mitílidos, estructura comunitaria, índices univariados, cloaca intermareal, Atlántico sudoccidental.

\section{Introduction}

Historically men have to disposal sewage. Coastal cities have solved this situation by dumping in the coastal line, being organic enrichment the oldest form of marine pollution (Pearson \& Rosenberg 1978). However, large cities settled on the shore have become the eutrophication in a common hazard in marine coastal areas in many parts of the world, with consequent potential damaging effects on both inshore fisheries and recreational facilities (Rosenberg 1985).

In the Southwestern Atlantic shore most (if not all) sewage discharge is still produced in shallow waters without any treatment or, like in the argentinian Mar del Plata City $\left(38^{\circ} \mathrm{S}-57^{\circ} \mathrm{W}\right)$, on the intertidal zone. The 
City has a permanent population of about 550,000 people, but during summer time, it receives more than $2,000,000$ tourists. The domestic sewage has a pretreatment plant that discharges a continuous flow with a mean rate of $2,5 \mathrm{~m}^{3} \cdot \mathrm{seg}^{-1}$, but in summer season reaches more than $4 \mathrm{~m}^{3}$.seg- ${ }^{1}$. The City needs a way to evaluate the extents and degree of man-caused impact in the marine environment.

The search for a cost-effective method for assessing environmental impact has a long history. From indicator species, or group of species, to community structure, men have attemped to found an unequivocal way to evaluate the extents and degree of the antropogenic effects. A complete framework was developed for the relationship between benthic communities and organic pollution, base on the response of soft-bottom macrobenthic communities from USA and Europe (Pearson \& Rosenberg 1978). This model predicts low values of species number in the vecinity of an organically enriched area, with great amount of individuals (opportunistic species). So, we can assess this kind of impact through indices that reflect this uneven individuals by species-distribution. Several measures have been proposed, being the Shannon diversity index H' (Shannon \& Weaver 1963), probably the most widespread employed in pollution ecology (Warwick \& Clarke 1993). The Shannon index has been incorporated in some programmes (like PRIMER, Plymouth Routines in Multivariate Ecological Research)(Plymouth Marine Laboratory 1994), and in Norway is part of the environmental legislation, and it is used to classified sediment quality (but see Gray 2000).

In contrast with soft-bottom models, only a few hard-bottom related studies have been carried out (i.e. Borowitzka 1972, Littler \& Murray 1978), most if not all in intertidal substrates dominated by algae. However, considering intertidal mussel beds affected by sewage, at last in one known case (using relative percent cover, and not all the species), the response of the intertidal community was opposite to the described model. Intertidal mussel beds developed as epilithic communities in the Southwestern Atlantic shore have shown an unsuspected behavior in community structure, being the lowest value of diversity and evenness (but no the species number) in not impacted areas, rather than in organically impacted ones (López Gappa et al. 1990, 1993).

So, is this behavior a common feature in intertidal mussel beds or is an exceptional case among a set of "classical" benthic response? In order to test this hypothesis, and to find a methodology easy and cheap to assess organic pollution in the Southwestern Atlantic shore, a spatial design with quantitative data along a predicted organically enrichment gradient was performed on a epilithic intertidal mytilid community developed in hard substrates exposed to domestic sewage.

\section{The Study area}

The sampling area is an open coast subjected to a longshore current (south to north) and to autumn-winter storms, with extense medium-sand beaches only interrupted by quartzitic outcrops and abrasion platforms of hard substrate. Around the effluent an abrasion platform is exposed to low tides, being azoics to the north (except for a few opportunistic algae), while to the south (to the City) they are cover by an unsuspected well developed mytilid community, where the study was carried out. These platforms are hard substrates of "caliche" (consolidated loess), characterized by an irregular and slowly slope (almost horizontal). Grooves lying perpendicular to the shoreline are common. Semidiurnal tides varies between 0.60 and $0.90 \mathrm{~m}$ (see Isla \& Ferrante 1997, Isla \& Aliotta 1999). Seawater have a range of temperature between 8 to $21^{\circ} \mathrm{C}$, and salinity between 33.5 to 33.8 psu, being considered as residual waters of the continental shelf (Guerrero \& Piola 1997).

\section{Material and methods}

During November of 1997, four Stations (1 to 4) were sampled south to the effluent (Fig. 1). In each Station two tidal levels were randomly sampled with a $78 \mathrm{~cm}^{2}$ corer into the mussel beds, 4 sampling units in the upper fringe (exposed in neap tides), and other 4 in the lower fringe (exposed in spring tides). The low level was absent from the Station 1. A Control Station (C) has also sampled $9 \mathrm{~km}$ north, where the intertidal community was developed in a similar intertidal hard substrate (Santa Elena Formation).

Environmental variables (Dissolved Oxygen, Turbidity, Temperature, Salinity and $\mathrm{pH}$ ) were measured in situ by a U-10 Horiba in each Station, and also in two wind conditions (North and East). Sediment samplings were obtained replicated in each level for determination of Total Organic Carbon (TOC, Walkley \& Black 1965). The material retained in a $1 \mathrm{~mm}$ screen mesh was separated and identificated under a stereomicroscope, but sediment accumulated between mussels were retained during sorting for total weight determination. Species richness, the Shannon diversity index (Shannon \& Weaver 1963) and evenness (Pielou 1969) were calculated for each sampling unit. 


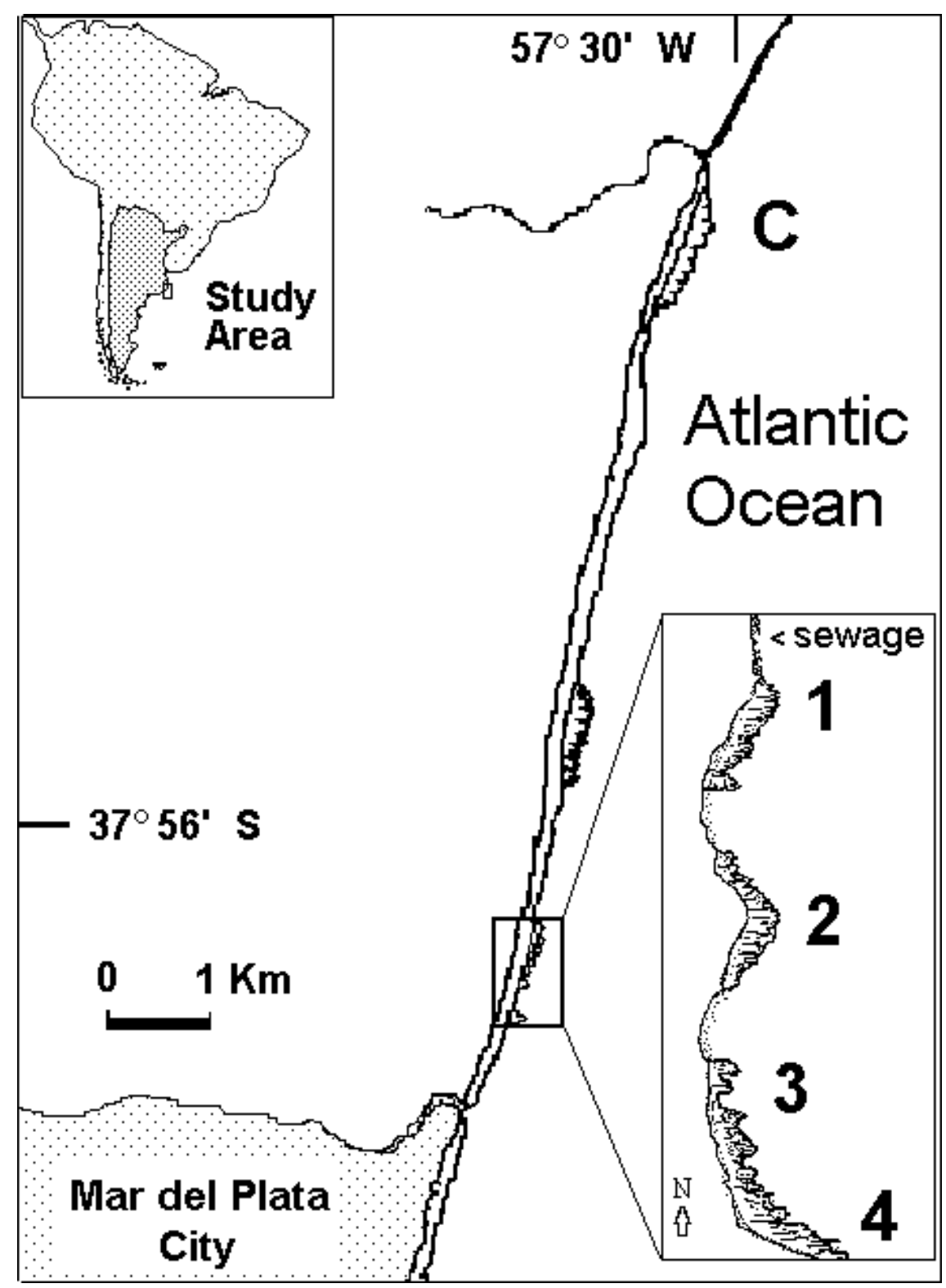

Figure 1

Sampling design in an abrasion platform affected by sewage inhabited by a mytilid community in the Southwestern Atlantic. The Station Control (C) is placed $9 \mathrm{~km}$ north to the effluent.

Diseño de muestreo en una plataforma de abrasión afectada por efluentes cloacales habitada por una comunidad de mitílidos en el Atlántico sudoccidental. La estación Control (C) está ubicada 9 km al norte del efluente.

Water quality data were analyzed using a two-way Anova, considering Stations and wind conditions, and differences in TOC and sediment weight were tested by a one-way Anova. Differences in densities between tidal levels and Species, and between Stations and Species were performed also with a one-way Anova. Biological analyses were performed on a reduced matrix with the 14 species of dominance up to $0.05 \%$. Both environmental and biological data (abundances) were double root transformed to achive homogeneity of variances (verified by the Cochran's C test). Whenever a difference was established in the Anova, a Post-hoc SNK test was performed to the appropiated alpha level. A Redundancy Analysis (RDA) was performed in order to determine the relationship between biological and environmental variables. For diversity analysis, the statistic Jack-Knife was utilized to test differences between all possible pair of Stations. 

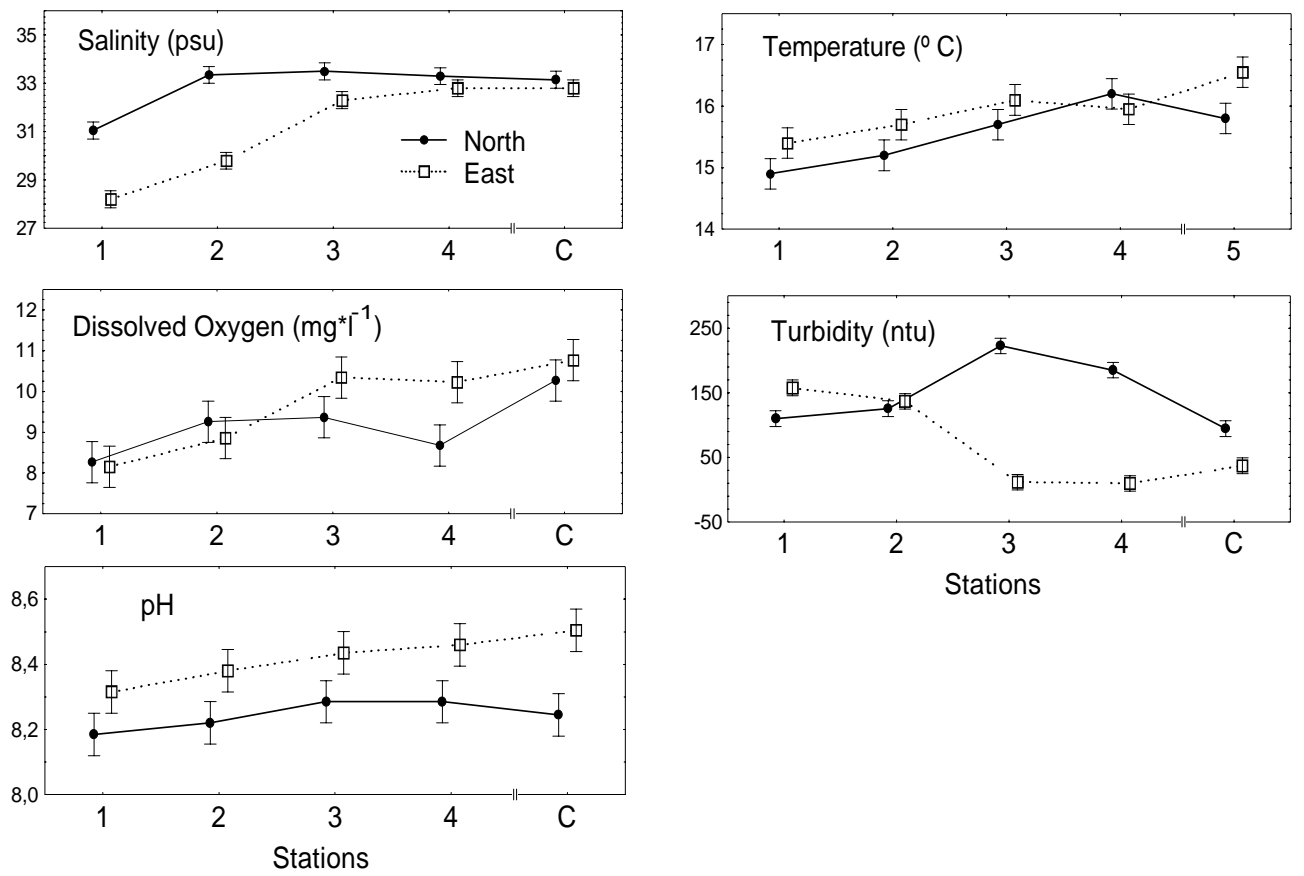

Figure 2

Mean values ( \pm sd) of environmental variables (Salinity, Temperature, Dissolved Oxygen, Turbidity, and pH) in impacted Stations (1 to 4) and Control Station (C) of the SW Atlantic shore in the two wind conditions.

Valores medios ( \pm ds) de variables ambientales (Salinidad, Temperatura, Oxígeno disuelto, Turbidez, y pH) en Estaciones impactadas (1 a 4) y Estación Control (C) de la costa SO del Atlántico en dos condiciones de viento.

\section{Results}

\section{Environmental variables}

The data were analyzed by a two-way Anova, considering Stations (1, 2, 3, 4 and C) and wind condition. The results shows a gradient according to distance to the effluent, but also a strong influence of the wind (Fig. 2). Differences due to Stations, Wind and Interactions were significative $(p<0.05)$. Planned comparison shows that Control Station (C) was different from Stations 1 to 4, and Station 1 differs from Stations 2, 3 and 4.

\section{Sedimentary pattern}

Total weight of sediments accumulated between mussels show a decreasing gradient from the control area (C) to the most impacted Station (1)(Fig. 3a), while TOC shows the opposite tendency, revealing the existence of an organically enrichment gradient (Fig. 3b). Post-hoc commparison shows that both parameters have highly significatives differences $(\mathrm{p}<0.01)$ between Stations $1-2$ and the rest.
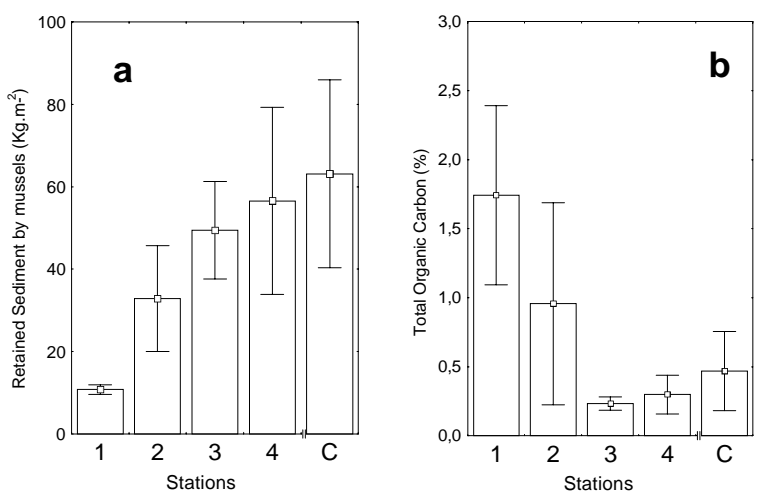

Figure 3

Mean ( \pm sd) of a: sediments accumulated between mussels $\left(\mathrm{Kg}^{-2} \mathrm{~m}^{-2}\right)$; b: Total Organic Carbon (\%) in sediments.

Station 1 is the closest to the intertidal sewage discharge and 4 the most far to the south; Station C (Control) is placed 9 km north.

Media ( \pm ds) de a: sedimentos acumulados entre bivalvos $\left(\mathrm{Kg}_{\mathrm{m}} \mathrm{C}^{-2}\right)$; b: Carbono orgánico total (\%) en sedimentos. La Estación 1 es la más cercana al efluente y la 4 la más lejana hacia el sur; la Estación C (Control) está 9 km al norte. 


\section{Community pattern}

About 43 species (36,667 individuals) were identified from the intertidal community. Mean dominance in the area corresponds to the mytilid Brachidontes rodriguezi (42.86 \%), the amphipods Jassa falcata (23\%) and Corophium insidiosum (12.9 \%), the polychaetes Syllis prolixa (7.66 \%) and Syllis gracilis (2.64 \%), and the caprellid Caprella sp. (4.15\%). The presence of the algae Enteromorpha sp., Bryopsis sp. and Cladophora sp. was constant, and in minor degree also for Ulva lactuca, but always in low frequency and abundance. Mytilus edulis platensis, the other mytilid in the area, varies between 0.35 to $3.6 \%$. However, spatial distribution is not even according to proportion and density, being the molluscs characteristic of the control Station (C), and polychaetes in Station 1, while crustaceans are dominant at intermediate Stations (Fig. 4).

A first analysis of differences in the community was conducted on tidal levels, being differences not significative; so all the sampling units were pooled for a one-way Analysis of Variance, being differences due to Station and Species significatives, as well as interactions (Table 1). Due to significative interactions, the benthic response was analyzed Station by Station.

In Station 1, community structure is characterized by the presence of Boccardia polybranchia (12.4\%), Capitella capitata (11.4 \%) and Corophium insidiosum (18\%), while the proportion of Brachidontes rodriguezi were low (38\%). Species number is low, but diversity and evenness were high (Fig. 5). Stations 2 and 3 (at 230 and $450 \mathrm{~m}$ from the effluent, respectively) present a variable proportion of the mytilid $B$. rodriguezi (between 15.5 to $33.5 \%$ ), and the associated fauna reach high abundance, mainly constituted by Jassa falcata (26 to $35 \%$ ) and C. insidiosum (14.6 a $39.9 \%$ ). In Station 4 (about $800 \mathrm{~m}$ from the effluent), $C$. insidiosum decreases in its dominance (6.7 to $9.7 \%$ ), while $J$. falcata is still dominant (30.8 to $47.5 \%$ ). The proportion of B. rodriguezi remains low (18.2 to 23.9 \%), due to the abundance of Caprella sp. (7.6 to 14.5 $\%)$ and the polychaete Syllis prolixa (10.8 to $16.7 \%$ ). Species number increases but diversity and evenness remains relatively constant in these three Stations (Fig. 5). Differences in diversity were also significative (Table 2).

In the control Station (C) B. rodriguezi is the dominant species (85\%) and Mytilus edulis platensis only reaches 1 to $1.3 \%$. The associated fauna were Syllis prolixa (3.8 to $4.8 \%$ ), Syllis gracilis (1.2 to 1.9 \%) and Jassa falcata (0.1 to 3.7 \%). Diversity reaches their minumum value, as well as evennes, but species number was not different from other Stations.

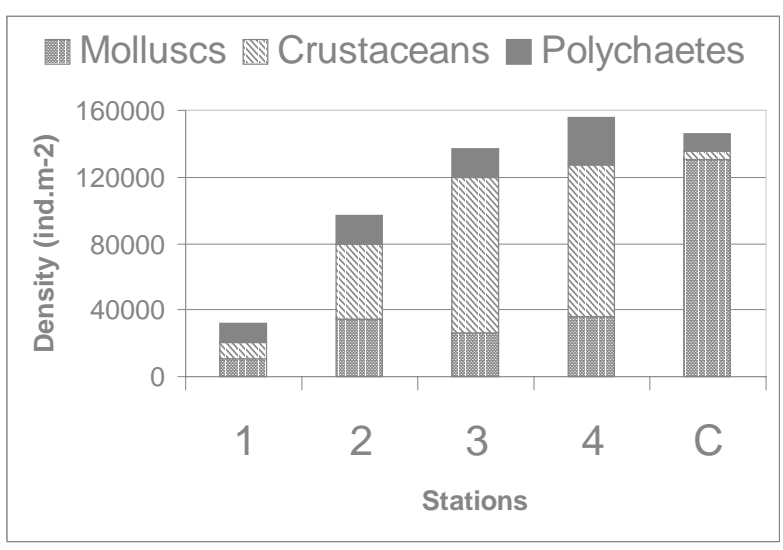

Figure 4

Mean density (ind. $\mathrm{m}^{-2}$ ) of the intertidal mussel community in the SW Atlantic shore affected by an organic gradient due to sewage.

Densidad media (ind. $\mathrm{m}^{-2}$ ) de la comunidad intermareal de bivalvos en la costa SO del Atlántico afectada por un gradiente orgánico debido a un efluente cloacal.
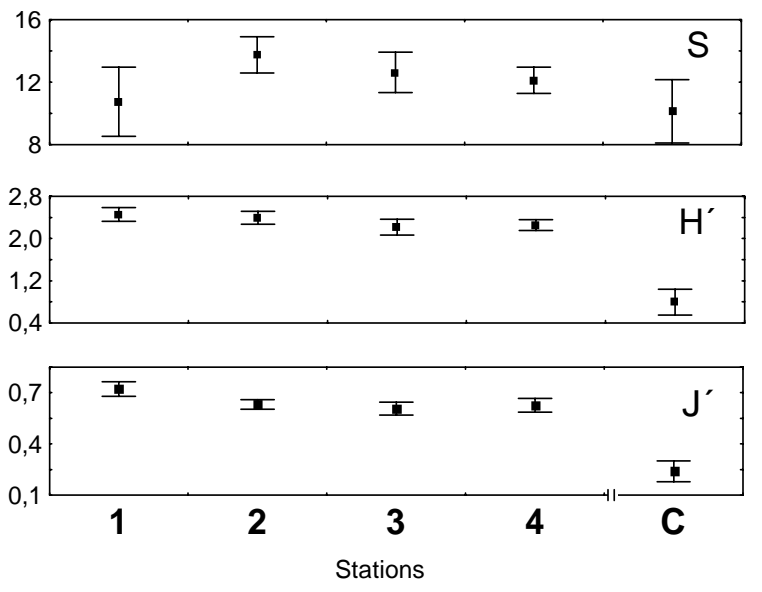

Figure 5

Species number (S), diversity (H' Shannon Index) and evenness ( $J$ ') in an intertidal mytilid bed affected by sewage in the Southwestern Atlantic shore. Organic gradient decreases from Stations 1 to 4 . Station $C$ is the Control site.

Número de especies (S), diversidad (índice H’ de Shannon) y equitatividad (J') en un banco de mitílidos intermareales afectados por un efluente cloacal en la costa SO del Atlántico. El gradiente orgánico disminuye desde la Estación 1 a la 4. La Estación C es el sitio Control. 
Table 1

Summary of all Effects in the two-way Anova (Stations and Species as Factors). ${ }^{*} \mathbf{p}<\mathbf{0 . 0 5}$ Resumen de todos los efectos del Anova de dos vías (Especies y Estaciones como factores). ${ }^{*} \mathrm{p}<0.05$

\begin{tabular}{|l|c|c|c|c|c|c|}
\hline & Df Effect & MS Effect & Df Error & MS Error & F & p-level \\
\hline Station & 4 & 2.90772 & 31 & 0.135830 & 21.4071 & $0.000000^{*}$ \\
\hline Species & 11 & 18.81903 & 341 & 0.060869 & 309.1751 & $0.000000^{*}$ \\
\hline Interaction & 44 & 2.04683 & 341 & 0.060869 & 33.6270 & $0.000000^{*}$ \\
\hline
\end{tabular}

Table 2

Values of $\mathbf{t}$ (Jack-Knife test) for H' diversity measurements in intertidal Stations affected by an organic enrichment gradient in the SW Atlantic shore. In parenthesis the degree of fredom. ${ }^{*} \mathbf{p}<0.05 ; * * \mathbf{p}<0.01 ; * * * \mathbf{p}<0.001$.

Valores de t (prueba de Jack-Knife) para mediciones de diversidad de H’ en estaciones intermareales afectadas por un gradiente de enriquecimiento orgánico en el Atlántico SO. En paréntesis los grados de libertad. ${ }^{*} \mathrm{p}<0.05 ;{ }^{* *} \mathrm{p}<0.01 ; * * \mathrm{p}<0.001$.

\begin{tabular}{|c|c|c|c|c|}
\hline & 1 & 2 & 3 & 4 \\
\hline 2 & $54.05 * * *(34)$ & & & \\
\hline 3 & $39.09 * * *(21)$ & $34.78 * * *(37)$ & & \\
\hline 4 & $2.63^{*}$ & $1.96 \mathrm{~ns}$ & $0.55 n s \quad(37)$ & \\
\hline $\mathrm{C}$ & $2.96 * * \quad(31)$ & $2.91^{* *} \quad$ (37) & $2.83 * * \quad(34)$ & $2.98 * * \quad(37)$ \\
\hline
\end{tabular}

\section{Redundancy Analysis}

The relationship of environmental and biological variables (Fig. 6) shows sampling units of impacted stations 1 and 2 related to TOC and Turbidity, associated to the polychaetes Capitella capitata and Boccardia polybranchia. In the opposite side of Axis I (that explain $54 \%$ of the total variance) the intermediate stations 3 and 4 were associated mainly to crustaceans and the polychaetes Syllis gracilis and Caulleriella alata, while the Control station were associated to Brachidontes rodriguezi, and the polychaetes Syllis gracilis and Protoariciella uncinata, highly related to $\mathrm{pH}$, dissolved oxygen, and sediment accumulated between mussels. Axis II (explaining a $39 \%$ of the variance) discriminate diverse stations (1, 2, 3 and 4) from poorly diverse station (Control site). However, considering only TOC and sediment between mussels (because the other environmental variables were highly correlated), explained variance of Axis I and II were 82 and $18 \%$, respectively.

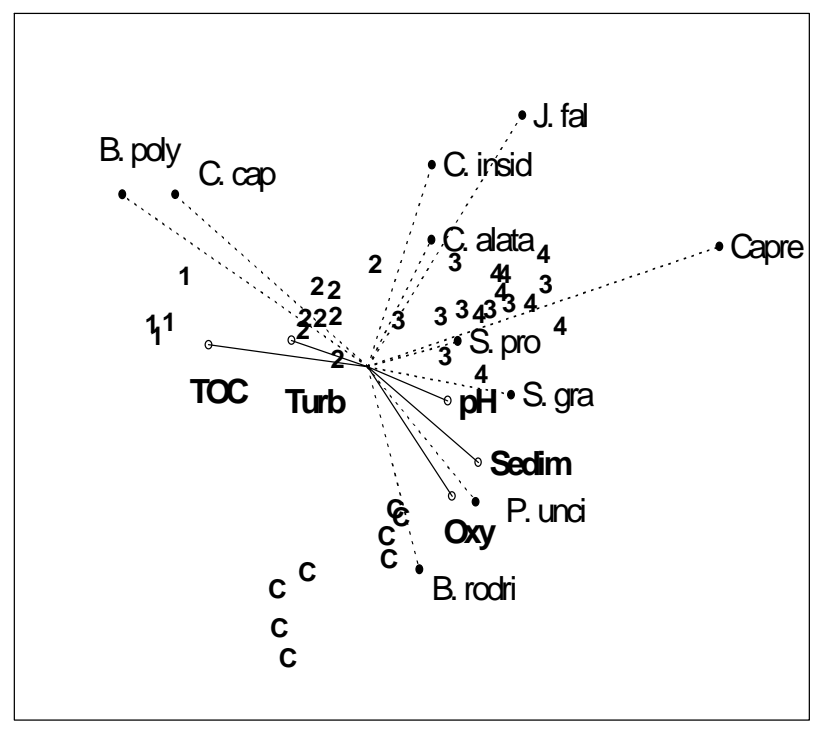

Figure 6

Redundancy analysis (RDA). Relationship of sampling units of Stations, Species, and environmental variables in the intertidal Brachidontes rodriguezi community exposed to sewage discharge. 1 to 4: Impacted Stations; C: Control site. B.poly: Boccardia polybranchia; C.cap: Capitella capitata; J.fal: Jassa falcata; C.insid: Corophium insidiosum; Capre: Caprella sp.; C.alata: Caulleriella alata; S.pro: Syllis prolixa; S.gra: Syllis gracilis; P.unci: Protoariciella uncinata; B.rodri: Brachidontes rodriguezi. TOC: Total Organic Carbon; Turb: Turbidity; Sed: Sediment accumulated between mussels; Oxy: Dissolved oxygen and pH.

Análisis de redundancia. Relación entre unidades de muestreo de las Estaciones, Especies y variables ambientales en la comunidad intermareal de Brachidontes rodriguezi expuesta a la descarga cloacal. 1 a 4: Estaciones impactadas; C: sitio Control; B.poly: Boccardia polybranchia; C.cap: Capitella capitata; J.fal: Jassa falcata; C.insid: Corophium insidiosum; Capre: Caprella sp.; C.alata: Caulleriella alata; S.pro: Syllis prolixa; S.gra: Syllis gracilis; P.unci: Protoariciella uncinata; B.rodri: Brachidontes rodriguezi.. TOC: Carbono orgánico total; Turb: Turbidez; Sed: Sedimento acumulado entre bivalvos; Oxy: Oxígeno disuelto; y pH. 


\section{Discussion}

Environmental data on water quality show a tipical gradient from the effluent, produced by the dilution of sewage discharge in the coastal waters. Parameters that reflect this pattern are $\mathrm{pH}$, Dissolved Oxygen, Salinity, and Turbidity. However, wind direction affected the distribution of sewage loadings. The flume has a variable behavior according to wind and tidal movements, being the southern coast affected by north wind, while the northern coast is affected by south and east winds (see Isla et al. 1998). Due to wind and longshore current (both predominantly south to north), north coast is severely affected by sewage, while to the south coast, average water quality allows the existence of a relatively well developed mytilid community.

Sediment composition also reflects the organic enrichment. An organically gradient is present from Station 1 to the south. However, the minimun value is observed in the intermediate Station 3 (perhaps due to the enbayment position). Sediments accumulated between mussels show the reverse, decreasing from Control sites to impacted areas, being the lowest value in Station 1, near the effluent, and the maximum value was recorded in the control site, where mytilid density is the greatest. It is a well known fact that mussel matrix retain sediments (see Seed \& Suchanek 1992), so the sediment retained is a denso-dependient variable, while density is a sewage-dependient factor. This could be seen in the RDA, in where the two factors (organic matter and sediments) and main species can explain the $100 \%$ of the variance.

The original description of the epilithic community shows that dominance in quartzitic rocks were established by the mytilid Brachidontes rodriguezi, reaching a mean dominance of $94 \%$ in the high intertidal to $59 \%$ in the lower intertidal, while Mytilus edulis platensis increases to the lower intertidal, from 0.59 to about 38 \% (Olivier et al. 1966, Penchaszadeh 1973). The disminution of the Mytilus dominance could not directly related to sewage effect, because other studies on this community also show the dominance (between 70 to $90 \%$ ) of B. rodriguezi, being Mytilus only ocasional, and always in low abundance (Scelzo et al. 1996).

On the other hand, in the Mar del Plata port the displacement of the mytilid community from intertidal areas was atributed to the pollution effect (Bastida et al. 1980) and to competitive exclution by barnacles (Vallarino \& Elías 1997). In the abrasion platforms affected by sewage, the proportion of the mytilid
Brachidontes rodriguezi remains low till the control areas, due to the negative effect of organic enrichment, and also for the presence and abundance of other species, tolerant to organic pollution.

Several polychaetes species were also found associated to this mussel beds, being Capitella capitata the dominant polychaete in organically impacted areas (5,448 ind.m- $\left.{ }^{2}\right)$, as well as the spionid Boccardia polybranchia $\left(5,833\right.$ ind.m- $\left.{ }^{2}\right)$. In enriched sediments associated to the blue mussel Mytilus edulis in Denmark, Svane \& Setyobudiandi (1996) have also found C. capitata and the spionid Polydora ciliata related to local hydrodinamics that increases both sedimentation and/or faeces and pseudofaeces. In the Wadden Sea $C$. capitata and $P$. ligni reach their highest average abundance inside Mytilus beds (4,000 and 3,000 ind. $\mathrm{m}^{-2}$, respectively), while in the adjacent areas of sand-flats did not exceed 750 ind. $\mathrm{m}^{-2}$ (Günther 1996). Capitella spp. are known to increase in patches enriched with organic matter (see Ragnarsson \& Rafaelli 1999), and in particular C. capitata is regarded as classical indicator of organic enrichment of sediments (see Pearson \& Rosenberg 1978, Pocklington \& Wells 1992). It is also known the relationship of spionids with organically enriched sediments (Pearson \& Rosenberg 1978). In intertidal areas of California (Dorsey et al. 1983) and in an Australian sewage (Dorsey 1982) Boccardia proboscidea was found in high abundances. In other abrasion platform of the Southwestern Atlantic shore, López Gappa et al. (1990) have found high densities of Boccardia sp. (up to 500,000 ind. $\mathrm{m}^{-2}$ ) between mussels and in sandy substrates at lower intertidal and subtidal areas at 50 to $100 \mathrm{~m}$ from sewage.

Other effects related to organic pollution is the great crustacean richness and density. Several species of Corophium have been mentioned in or around pollution areas (Pearson \& Rosenberg 1978). C. insidiosum was found in many works on the South Atlantic shore, but is the first time that their occurrence in high densities are registred in relation to a mussel beds affected by sewage. Caprella sp. and Jassa falcata are common members of this community, but never have been registered in densities of thousands. J. falcata was also subdominant in subtidal mytilids beds of the Mediterranean Sea at intermediate distances from pollution sources (Bitar 1982). Günther (1996) also observed an increasing abundance of mobile epifauna (mainly crustaceans) inside the Mytilus beds compared to adjacent flat.

This most impacted Station (1) has high diversity and evenness. Although species number are the lowest 
of the sampled area, the numerical distribution of indicator species and Brachidontes rodriguezi are more even that in other areas far from the effluent. Diversity index, like Shannon's, would be useful in detection of pollution, because we expected that impacted areas had lower values than non-impacted ones. However, the example of the intertidal community in this part of South America shows an opposite effect, being the lowest values of H' and J' in the "normal" community due to the dominance of mytilids. López Gappa et al. (1990), studying the same epilithic mytilid community $120 \mathrm{~km}$ south to Mar del Plata City, found the same pattern in a similar abrasion platform (but tidal level corresponds mostly to a more high level, and using relative percent cover). These authors conclude, like Osman (1977), that there is an optimun degree of disturbance at which diversity reaches a maximum. Near the effluent, the low species number was due to the negative effects of organic pollution, while in the Control site the drop in both diversity and evenness (rather than in species number) was due to the space monopolization by Brachidontes rodriguezi. The optimum degree of disturbance by domestic sewage seems to be between 200 to $800 \mathrm{~m}$ far from the effluent, in where highly density of associated fauna (mainly crustaceans and polychaetes) and high diversity values were observed. Trends in epilithic intertidal community showed herein at the spatial scale can be observed also along a series of short-term studies (Vallarino, pers. com., 2001).

In the same way, Warwick \& Clarke (1993) show that variability (standard desviation) in diversity ( $\left.\mathrm{H}^{\prime}\right)$ tends to increase with increasing levels of perturbation (only significative for macrobenthos). In the present work this tendency was rejected, because Station 1 (the most impacted) shows the lowest species number, but the highest diversity and evenness values (see Figure 5), and also shows a similar variability with the Control Station, however differences are highly significative in diversity values (see Table 2). In agreement with Del Valls \& Conradi (2000) the uncertainty and high variability inherent in both ecosystems and methods of measurement require a range of values and a burden-ofevidence approach. Ultimately, judgements on environmental quality, assuming the persistence of habitat, can only be determined by the responses or condition of multiple (but never single or a large number of) measurements conducted as part of integrative assessments. Gray (2000) have demonstrated that Shannon index is insensitive, showing little variation along a transect survey carried out in the Norwegian Shelf, and that the use of multivariate statistics gives a much more precise way of detecting changes in benthic assemblages. However, the Shannon index is still successfuly used in assessment of pollution. In subtidal areas of this study area the index has revealed to be usefull for this kind of studies (Elías et al. 2001).

In this community, the classic response to organic pollution is the presence and abundance of indicator species (mainly polychaetes), while the new one is the utilization of the proportion of mytilids as the most powerful method for assessing organic pollution from sewage discharge in the Southwestern Atlantic shore.

\section{Aknowledgements}

This work was primarily supported by the authors, but the enterprise Obras Sanitarias Sociedad de Estado (OSSE) provided funding (1999) to continue the project. This study constitutes part of the Ph.D. project developed by E.A. Vallarino.

\section{Literature Cited}

Bastida RO, M Trivi, V Lichtschein de Bastida \& M Stupak. 1980. Ecological aspects of marine fouling at the port of Mar del Plata (Argentine). V Congreso Internacional de Corrosión Marina e Incrustaciones. Marine Biology: 299-320.

Bitar G. 1982. Influence d'un grand émisaire urbain sur la distribution du zoobenthos de sustrat dur dans la région de Marseille (Mediterranée nord-occidentale). Tethys 10: 200-210.

Borowitzka MA. 1972. Intertidal algal species diversity and the effect of pollution. Australian Journal of Marine and Freshwater Research 23: 73-84.

Del Valls TA \& M Conradi. 2000. Advances in marine ecotoxicology: Laboratory tests versus field assessment data on sediment quality studies. Ciencias Marinas 26: 3964.

Dorsey JH. 1982. Intertidal community offshore from the Werribee sewage-treatment farm: An opportunistic infaunal assemblage. Australian Journal of Marine and Freshwater Research 33: 45-54.

Dorsey JH., KD Green \& RC Rowe. 1983. Effects of sewage disposal on the polychaetous Annelids at San Clemente Island, California. In: Soule, DF \& D Walsh (eds), Waste Disposal in the Oceans. Minimizing Impact, Maximizing Benefits 13: 209-233. Southern California Academy of Sciences.

Elías R, CS Bremec \& EA Vallarino. 2001. Polychaetes from a southwestern shallow shelf Atlantic area (Argentina, $38^{\circ} \mathrm{S}$ ) affected by sewage discharge. Revista Chilena de Historia Natural 74: 523-531.

Gray JS. 2000. The measurement of marine species diversity, with an application to the benthic fauna of the Norwegian continental shelf. Journal of Experimental Marine Biology and Ecology 250: 23-49. 
Guerrero RA. \& AR Piola 1997. Masas de agua en la plataforma continental. In: Boschi, EE (ed.), El mar Argentino y sus recursos pesqueros 1. pp. 107-118. Instituto Nacional de Investigación y Desarrollo Pesquero (INIDEP), Mar del Plata, Argentina.

Günther CP. 1996. Development of small Mytilus beds and its effects on resident intertidal macrofauna. Publicazzione di l'Station Zoologica di Napoles Marine Ecology 17: 117-130.

Isla FI. \& A Ferrante 1997. Corrientes. In: Isla, FI. (ed), Estudio del sector de plataforma receptor de la descarga cloacal de Camet, Mar del Plata. Chapter 5. pp. 63-116. Facultad de Ciencias Exactas y Naturales, Universidad Nacional de Mar del Plata.

Isla FI, J Perez Guzzi, A Zamora \& A Folabella. 1998. Aportes de coliformes a la costa de Mar del Plata (Argentina) por vías naturales e inducidas. Thalassas 14: 63-70.

Isla FI \& S Aliotta. 1999. Storm Dispersal of Volcanogenic Sands from Buenos Aires, Where Heavy-Metal concentrations Are Heavy-Mineral Segregations. Marine Georeearch. Geotechnology 17: 357-370.

Littler MM \& SN Murray. 1978. Influence of domestic wastes on energetic pathways in rocky intertidal communities. Journal of Applied Ecology 15: 583-595.

López Gappa JJ, A Tablado \& NH Magaldi. 1990. Influence of sewage pollution on a rocky intertidal community dominated by the mytilid Brachydontes rodriguezi. Marine Ecology Progress Series 63: 163-175.

López Gappa JJ, A Tablado \& NH Magaldi. 1993. Seasonal changes in an intertidal community affected by sewage pollution. Environmental Pollution 82: 157-165.

Olivier SR, A Escofet, JM Orensanz, SE Pezzani, AM Turro \& ME Turro. 1966. Contribución al conocimiento de las comunidades bénticas de Mar del Plata. I. El litoral rocoso entre Playa Grande y Playa Chica. Anales de la Comisión de Investigaciones Científicas de la Provincia de Buenos Aires 7: 185-206.

Osman R. 1977. The establishment and development of a marine epifaunal community. Ecological Monograph 47: 37-63.

Pearson TH \& R Rosenberg. 1978. Macrobenthic succession in relation to organic enrichment and pollution of the marine environment. Oceanography Marine Biology Annual Review 16: 229-311.

Penchaszadeh P. 1973. Ecología de la comunidad del mejillín (Brachidontes rodriguezi, D’Orb.) en el mediolitoral rocoso de Mar del Plata (Argentina): el proceso de recolonización. Physis A 32: 51-64.
Pielou EC. 1969. An introduction to mathematical ecology. Wiley-Interscience, New York, 286 pp.

Plymouth Marine Laboratory 1994. PRIMER - Plymouth Routines in Multivariate Ecological Research. Plymouth U.K. Version prepared for training workshop at Laboratorio Costero San José, Callao, Perú, April 1997: 151.

Pocklington P \& PG Wells. 1992. Polychaetes. Key taxa for marine environmental quality monitoring. Marine Pollution Bulletin 24: 593-598.

Ragnarsson SA \& D Rafaelli. 1999. Effects of the mussel Mytilus edulis L. on the invertebrate fauna of sediments. Journal of Experimental Marine Biology and Ecology 241: 31-43.

Rosenberg R. 1985. Eutrophication -the Future Marine Coastal Nuisance? Marine Pollution Bulletin 16: 227-231.

Scelzo MA, R Elias, EA Vallarino, M Charrier, N Lucero \& F Alvarez. 1996. Variación estacional de la estructura comunitaria del bivalvo intermareal Brachidontes rodriguezi (D’Orbigny, 1846) en sustratos artificiales (Mar del Plata, Argentina). Neritica 10: 87-102.

Seed R \& TH Suchanek. 1992. Population and community ecology of Mytilus. In: E Gosling (ed), The mussel Mytilus: ecology, physiology, genetics and culture. Development in Aquaculture and Fisheries Science 25: 87-170.

Shannon CE \& W Weaver. 1963. The mathematical theory of communication. Urbana, University of Illinois Press. $117 \mathrm{pp}$.

Svane I \& I Setyobudiandi. 1996. Diversity of associated fauna in beds of the blue mussel Mytilus edulis L.: effects on location, patch size and position within a patch. Ophelia 45: 39-53.

Vallarino EA \& $\mathbf{R}$ Elias. 1997. The dynamics of an introduced Balanus glandula population in the Southwestern Atlantic rocky shores. The consequences on the intertidal community. Publicazzione di l'Station Zoologica di Napoles Marine Ecology 18: 319-335.

Walkley A \& A Black. 1965. Chapter 4. In: Black, A \& J Evans (eds), Method of soils analysis. American Society of Agronomy, Madison, USA. 219 pp.

Warwick RM \& KR Clarke. 1993. Increased variability as a symptom of stress in marine communities. Journal of Experimental Marine Biology and Ecology 172: 215-226. 